Bangladesh J. Sci. Ind. Res. 42(2), 195-202, 2007

\title{
Study on Energy Input, Output and Energy Use Efficiency of Major Jute Based Cropping Pattern
}

\author{
M. A. Khan ${ }^{\mathrm{a}}$ and S. M. A. Hossain \\ ${ }^{a}$ Jute Research Regional Station, Bangladesh Jute Research Institute, Rangpur and \\ ${ }^{b}$ Department of Agronomy, BAU, Mymensingh, Bangladesh.
}

\begin{abstract}
An investigation was undertaken in Jute Research Regional Station, BJRI, Kishoreganj during the period of 2000 - 2001 to 2002 - 2003 to evaluate the energy input, energy output and output-input ratio of some selected jute based cropping pattern. the result showed that the highest energy input (42,928 $\left.\mathrm{MJ} \mathrm{ha}^{-1}\right)$ was noted for Jute (oli.)- T. aman rice-Potato, which was closely followed by Jute (cap.)-T. aman rice-Potato cropping pattern (39.856 $\mathrm{MJ} \mathrm{ha}^{-1}$ ). The lowest energy input (19,947 MJ $\mathrm{ha}^{-1}$ ) was found for Jute (cap.)-T. aman rice-Fallow pattern. The highest energy output from main product was recorded in Jute- T. aman rice-Potato cropping pattern while the lowest from Jute-Fallow-Wheat pattern. However, the highest total energy output was obtained from Jute-T. aman rice-Wheat (4,01,332-403851 MJ ha-1) which was followed by Jute-T. aman rice-Potato (3,66,729-3,73,949 $\mathrm{MJ} \mathrm{ha}^{-1}$ ) and Jute-T. aman rice-Lentil (2,88,906-3,33,416 $\left.\mathrm{MJ} \mathrm{ha}^{-1}\right)$, although the energy output from main product of potato containing cropping pattern was the highest. The energy output from by-product was more compared to main product for all the cropping patterns. Between two jute based cropping patterns, olitorius jute containing pattern required higher energy input than that of capsular is but energy output was higher in capsularis jute containing pattern. Output-input ratio of cropping pattern was maximum (14.5) in 2-crop pattern where rabi crops were absent. It indicated that rabi crops had lower energy output compared to other kharif crops.
\end{abstract}

\section{Introduction}

Jute is the main cash crop of Bangladesh. There are 0.4 to 0.5 millions hectare of land cultivated under jute. Jute crop generally grow in medium high land under non-irrigat- ed area. The major cropping patterns of this country in medium high land under rainfed condition are Rabi crops-Aus rice-T. aman rice, Fallow-Aus rice-T. aman rice, Fallow- 
Jute-T. aman rice and Wheat-Aus riceFallow (Khan, et al., (1987). The production of crops in a system with high yield targets cannot be achieved without energy inputs to the system. The energy input is one of the key factors for successful crop production. Energy requirements for crop production system have been witnessing a dramatic diversification in agriculture. Intensive agriculture involving high intensity cropping systems requires larger amounts of energy. Energy input pattern for crop production depends on economic, technological and social constraints. Commercial and non-commercial energy are available in agricultural operations. Commercial energy inputs arrive on farm in many different forms e.g. fuel, irrigation water, chemical fertilizer, machinery and pesticides. Non-commercial energy is available as solar radiation and wind (Kiamco and McMennany, 1979). Increase in crop productivity is mainly realized through commercial energy sources i.e., chemical fertilizers, fuel and electricity (Bohra and Maheshwari, 1983). However, the power utilization in farm level usually varies with farm size, crop grown, production practices and physical environment (Sarker, 2000). Among the field crops, legumes involve much less energy than cereals and oilseeds. Rice production incurs much higher input of energy, mainly due to its high water and fertilizer requirements coupled with other practices like transplanting, harvesting and threshing. Gautam (Gautam, 1979) estimated that the tillage operations, fertilizers and pesticides took about $70 \%$ of the energy required for crop production and fertilizer alone accounted about $40 \%$. Amongst fertilizers, nitrogen accounted for maximum energy input in crop production.

Parihar (Parihar, et al., 1999) studied the energy requirement of seven different ricebased cropping systems. Among the different cropping systems Rice-Rice required the highest energy input (27.35 x $\left.103 \mathrm{MJ} \mathrm{ha}^{-1}\right)$ while Rice-Chickpea the lowest (17.70 x 103 MJ ha ${ }^{-1}$ ). Rice-Rice system produced the highest output energy followed by ricepeanut. Baishya and Sharma (Baishaya, and Sharma, 1990) observed in relation to energy output, rainfed crops of rice and wheat in rice-wheat sequence performed better under resource constraint condition. However, increase the cost of commercial energy and decline in fuel reserves warm the researcher to workout highly productive cropping system with better energy use efficiency. therefore, a study was undertaken to evluate the energy input, energy output and energy use efficiency of some selected jute based cropping pattern.

\section{Materials and Methods}

The study was conducted at Jute Research Regional Station, BJRI, Kishoreganj during 2000-2003. The soil of experimental plot was silt loam in texture, slightly acidic ( $\mathrm{pH}$ 6.17), low in organic carbon (0.72\%), total nitro- 
gen $0.072 \%$ ) and exchangeable potassium (0.074 meq./100g), had optimal level of phosphorus (32.0 ppm) and available sulpher near about critical level (14.0 ppm). The study was consisted with ten jute based cropping patterns, i.e., i) Jute (cap.)-T. aman riceWheat, ii) Jute (oli.)-T. aman rice-Wheat, iii) Jute (cap.)-T. aman rice-Potato, iv) Jute (oil.)-T. aman rice-Potato, v) Jute (cap.)-T. aman rice-Lentil, vi) Jute (oli.)-T. aman riceLentil, vii) Jute (cap.)-T. aman rice-Fallow, viii) Jute (oli.)-T. aman rice-Fallow, ix) Jute (cap.)-Fallow-Wheat and x) Jute (oli.)Fallow-Wheat. The treatments were replicated four times in randomized complete block design with a plot size of $4.0 \mathrm{~m} \times 5.0 \mathrm{~m}$. Sowing of rabi crops some what delayed in 1 st year and 3rd year due to rain at late November. All crops were grown with recommended package of practices. Supplemental irrigation was applied in transplanted aman rice whenever it necessary. The wheat and potato crops were irrigated once at the vegetative stage.

\section{Energy input and output}

Total energy input and output of crops and cropping systems were estimated by using the energy equivalents (Table I) as suggested by many worders (Eusuf, et al., 1987; Hassan and Ahmad, 1990; Mittal and Dhawan, 1988). The energy input through land preparation, seed bed preparation, seed sowing, transplanting, fertilizer and pesticide applica- tion, intercultural operations. irrigation, harvesting, carrying, threshing and drying expressed as human labour, seed, fertilizer, pesticide and fuel use for irrigation and land preparation were calculated. The energy input from non-commercial sources was ignored because this energy was coming from natural sources. The energy output was calculated by accumulating the main product and by-product produced from different cropping systems. Subtracting input energy from output energy derived the net return of energy. The output-input ratio was worked out by dividing the total energy generated from main product and by-product by the total energy used for raising the crop in the unit area. The energy input and output were computed as Mega Joule (MJ) by following formula :

\section{Energy input $=E_{h l}+E_{p r}+E_{m t}$}

where, $\mathbf{E}_{\mathbf{h l}}=$ energy from human labour

$$
\begin{aligned}
& \mathbf{E}_{\mathbf{p r}}=\text { energy from power } \\
& \mathbf{E}_{\mathbf{m t}}=\text { energy from materials likes }
\end{aligned}
$$
seed, fertilizer, pesticides and irrigation etc.

\section{Energy output $=E_{m p}+E_{b p}$}

Where, $\mathbf{E}_{\mathbf{m p}}=$ energy from main product

$$
\mathbf{E}_{\mathbf{b p}}=\text { energy from by-product }
$$

Details conversion procedures are presented in the following Table. 
Table I. Energy co-efficient of different input and outputs

\begin{tabular}{|c|c|c|c|}
\hline \multicolumn{2}{|c|}{ Inputs (MJ kg $\left.{ }^{-1}\right)$} & \multicolumn{2}{|l|}{ Outputs (MJ kg-1) } \\
\hline 1. Seed & & 1. Main product & \\
\hline i) Jute & 16.91 & i) Jute fibre (cap.) & 19.12 \\
\hline ii) Rice & 14.70 & ii) Jute fibre (oli.) & 17.84 \\
\hline iii) Wheat & 14.70 & iii) Rice grain & 14.70 \\
\hline iv) Potato & 4.06 & iv) Wheat grain & 14.70 \\
\hline v) Lentil & 14.40 & v) Lentil grain & 14.40 \\
\hline vi) Dhaincha & 14.70 & vi) Potato tuber & 4.06 \\
\hline 2. Fertilizer & & 2. By-product & \\
\hline i) $\mathrm{N} 60.10$ & & i) Jute stick 16.91 & \\
\hline ii) P 11.10 & & ii) Rice straw 15.59 & \\
\hline iii) K 11.10 & & iii) Wheat straw 15.76 & \\
\hline iv) Lentil stover & 12.50 & & \\
\hline 3. Agrochemicals & & & \\
\hline i) Solid/powder & 12.00 & & \\
\hline ii) Liquid & 120.00 & & \\
\hline 4. Diesel & $56.31 \mathrm{MJ} \mathrm{L}^{-1}$ & & \\
\hline 5. Human labour & $1.96 \mathrm{MJ} \mathrm{hr}^{-1}$ & & \\
\hline
\end{tabular}

\section{Results and Discussion}

\section{Energy input in cropping patterns}

Energy inputs at different stages of crop production such as seed bed preparation, seed sowing, transplanting, fertilizing, pest management, intercultural operations, irrigation, harvesting, carrying, threshing and drying that expressed as energy obtained from human labour, materials (seed, fertilizer and pesticides) and fuel are presented in Table II. Total energy inputs in different cropping patterns under this study was in range from 19,947 to 42,928 $\mathrm{Mj} \mathrm{ha}^{-1}$. In general, fertilizer accounted for a major share of energy input (39.4-49.2 \%) followed by human labour (20.4-29.8\%) and fuel use for irrigation and land preparation (19.3-25-8 \%). The energy input $(0.2-0.9 \%)$ through pesticide was minimum followed by seed (3.2-17.2 \%). Islam (et al., 2001) reported that the fertilizer contributed the largest energy input (47 \% - $50 \%$ ) in different cropping systems. Three years average data showed that the Jute (oli.)-T. aman rice-Potato recorded the highest energy input $\left(42,928 \mathrm{MJ} \mathrm{ha}^{-1}\right)$, which was closely followed by Jute (cap.)-T. aman rice-Potato cropping pattern $\left(39,856 \mathrm{MJha}^{-1}\right)$. 
Table II. Energy input in different cropping patterns (mean data of 3 years)

\begin{tabular}{l|c|c|c|c|c|c}
\hline Cropping pattern & $\begin{array}{c}\text { Labour } \\
\left(\mathrm{MJ} \mathrm{ha}^{-1}\right)\end{array}$ & $\begin{array}{c}\text { Seed } \\
\left(\mathrm{MJ} \mathrm{ha}^{-1}\right)\end{array}$ & $\begin{array}{c}\text { Fertilizer } \\
\left(\mathrm{MJ} \mathrm{ha}^{-1}\right)\end{array}$ & $\begin{array}{c}\text { Pesticide } \\
\left(\mathrm{MJ} \mathrm{ha}^{-1}\right)\end{array}$ & $\begin{array}{c}\text { Fuel } \\
\left(\mathrm{MJ} \mathrm{ha}^{-1}\right)\end{array}$ & $\begin{array}{c}\text { Total ener- } \\
\text { gy input } \\
\left(\mathrm{MJha}^{-1}\right)\end{array}$ \\
\hline 1. Jute (cap.)-T. aman rice-Wheat & 7317 & 2539 & 14027 & 184 & 7883 & 31950 \\
2. Jute (oli.)-T. aman rice-Wheat & 7338 & 2501 & 17012 & 198 & 7883 & 34932 \\
& $(21.0)$ & $(7.2)$ & $(48.7)$ & $(0.6)$ & $(22.6)$ & \\
3. Jute (cap.)-T. aman rice-Potato & 8740 & 6865 & 15693 & 280 & 8278 & 39856 \\
& $(21.9)$ & $(17.2)$ & $(39.4)$ & $(0.7)$ & $(20.8)$ & \\
4. Jute (oli.)-T. aman rice-Potato & 8760 & 6827 & 18769 & 294 & 8278 & 42928 \\
& $(20.4)$ & $(15.9)$ & $(43.7)$ & $(0.7)$ & $(19.3)$ & \\
5. Jute (cap.)-T. aman rice-Lentil & 7140 & 1207 & 9646 & 184 & 6307 & 24484 \\
& $(29.2)$ & $(4.9)$ & $(39.4)$ & $(0.8)$ & $(25.8)$ & \\
6. Jute (oli.)-T. aman rice-Lentil & 7160 & 1169 & 12722 & 198 & 6307 & 27556 \\
& $(26.0)$ & $(4.2)$ & $(46.2)$ & $(0.7)$ & $(22.9)$ & \\
7. Jute (cap.)-T. aman rice-Fallow & 5953 & 775 & 7911 & 184 & 5124 & 19947 \\
& $(29.8)$ & $(3.9)$ & $(39.7)$ & $(0.9)$ & $(25.7)$ & \\
8. Jute (oli.)-T. aman rice-Fallow & 5974 & 737 & 10995 & 198 & 5124 & 23028 \\
& $(25.9)$ & $(3.2)$ & $(47.8)$ & $(0.9)$ & $(22.2)$ & \\
9. Jute (cap.)-Fallow-Wheat & 5153 & 1951 & 9182 & 40 & 5518 & 21844 \\
& $(23.6)$ & $(8.9)$ & $(42.0)$ & $(0.2)$ & $(25.3)$ & \\
10. Jute (cap.)-Fallow-Wheat & 5174 & 14913 & 12246 & 54 & 5518 & 24905 \\
& $(20.8)$ & $(7.7)$ & $(49.2)$ & $(0.2)$ & $(22.2)$ & \\
\hline
\end{tabular}

Figures in parentheses indicate the percentage of total energy inputs.

The next highest energy input was recorded in Jute (oli.)-T. aman rice- Wheat pattern (34,932 $\left.\mathrm{MJ} \mathrm{ha}^{-1}\right)$. The next highest energy input was recorded in Jute (oli.)-T. aman rice-Wheat pattern (34,932 $\left.\mathrm{MJ} \mathrm{ha}^{-1}\right)$ followed by Jute (cap.)-T aman rice-Wheat (31,950 $\left.\mathrm{MJ} \mathrm{ha}^{-1}\right)$. The lowest energy input was required for Jute (cap.)-T. aman rice-Fallow (19,999 $\mathrm{MJ} \mathrm{ha}^{-1}$ ) followed by Jute (cap.)-
Fallow-Wheat (21,881 $\left.\mathrm{MJ} \mathrm{ha}^{-1}\right)$, whcih was obvious for a two-crop pattern. The highest energy inputs required for potato containing cropping pattern might be due to the use of costly inputs like seed, fertilizer, pesticides and irrigation. The three-crop pattern with a wheat required inputs energy next to potato containing pattern. The lentil containing three-crop pattern required lower energy 
input compared to wheat or potato containing pattern. Between the jute based cropping patterns, olitorius, jute containing pattern required higher energy than did capsularis jute-containing pattern due to higher inputs required for olitorius jute. (Parihar et al., 1999) reported the total energy input in RiceWheat, Rice-Rice and Rice-Chickpea pattern were 24,370 MJ ha' $27359 \mathrm{MJ} \mathrm{ha}^{-1}$ and $17,700 \mathrm{MJ} \mathrm{ha}^{-1}$, respectively.

\section{Energy output of different cropping patterns}

Total energy output from main product and by-product of different cropping patterns were computed and it was range from 24,9506 to 40,3851 $\mathrm{MJ} \mathrm{ha}^{-1}$ (Table III). The highest total energy output was obtained from Jute-T. aman rice-Wheat (40,133240,3851 $\mathrm{MJ} \mathrm{ha}^{-1}$ ) followed by Jute-T. aman rice-Potato (36,6729-37,3949 $\left.\mathrm{MJ}^{\mathrm{h}} \mathrm{h}^{-1}\right)$ and Jute-T. aman rice-Lentil (33,3416-34,1982 $\mathrm{MJ} \mathrm{ha}^{-1}$ ). The next highest energy output was obtained from 2-crop pattern Jute-T. aman rice-Fallow $\left(28,5267-28,8906 \mathrm{MJ} \mathrm{ha}^{-1}\right)$. The lowest energy output was obtained from JuteFallow-Wheat (24,9506 - 26,1818 MJ ha-1). Wheat containing jute based cropping pattern produced highest energy output might be due to higher by-product energy of wheat compared to other rabi crops. Energy output from main product ranged from 1,65,398 $\mathrm{MJ} \mathrm{ha}^{-1}$ to $2,58,569 \mathrm{Mj} \mathrm{ha}^{-1}$ (Table IV). It was might be due to the higher yield of by-product of different component crops of the pattern. The highest energy output of main product was obtained from the Jute (oli.)-T. aman ricePotato (1,77,979 $\mathrm{MJ} \mathrm{ha}^{-1}$ ) and Jute (cap.)-T. aman rice-Potato $\left(1,76,881 \mathrm{MJ} \mathrm{ha}^{-1}\right)$ patterns. The next highest energy output was recorded with the Jute (cap.)-T. aman rice-Wheat (1,45,282 MJ ha-1), which was followed by Jute (oli.)-T. aman rice-Wheat (1,44,589 MJ $\mathrm{ha}^{-1}$ ) cropping patterns. The energy output from lentil containing 3-crop pattern was lower than that of potato and wheat containing pattern. The lowest energy output of main product was recorded from 2-crop pattern Jute-Fallow-Wheat. Potato containing cropping pattern produced higher main product energy due to higher productivity of potato tuber compared to other rabi crops, but it was not so high like main product yield because of higher percentage of moisture and less amount of calorie (energy) in potato tuber.

The highest by-product energy was obtained from the Jute (cap.)-T. aman rice-Wheat (2,58,569 $\mathrm{MJ} \mathrm{ha}^{-1}$ ) and Jute (oli.)-T. aman rice-Wheat pattern $\left(2,56,743 \mathrm{MJ} \mathrm{ha}^{-1}\right)$ followed by Jute (cap.)-T. aman rice-Lentil (1,97,068 $\mathrm{MJ} \mathrm{ha}^{-1}$ ) and Jute (Oli.)-T. aman rice-Lentil (1,88,750 $\mathrm{MJha}^{-1}$ ) cropping pattern (Table III). The lowest energy output of by-product was recorded in Jute (oli.)Fallow-Wheat $\left(1,65,398 \mathrm{MJ} \mathrm{ha}^{-1}\right)$ followed by Jute (ca.)-Fallow-Wheat (1,73,638 MJ ha$\left.{ }^{1}\right)$ pattern. The result also indicated that the energy output from by-product was higher than that of main product for all the cropping 
patterns. this result agreed with the findings of Guruswamy (Gurusawmy, et al., 1992). However, the potato containing cropping pattern Jute (cap./oli.)-T. aman rice-Potato produced lower by-product energy compared to wheat and lentil containing pattern due to lack of by-product energy from potato crops. Between the two jute species based cropping patterns capsularis jute gave higher energy output from by-product compared to olitorius jute.

\section{Output-input ratio of different cropping pattern}

Among the cropping patterns, the highest energy output-input ratio of 14.5 was obtained from Jute (cap.)-T. aman riceFallow followed by 14.0 of Jute (cap.)-T. aman rice-Lentil and the lowest of 8.5 in Jute
(oli.)-T. aman rice-Potato cropping pattern (Table III). The result indicates that the energy output from rabi crops was not remunerative compared to the other component crops of the pattern. The higher energy outputinput ratio in lentil involving jute based cropping pattern was appeared due to lower energy input required for lentil compared to other rabi crops. (Parihar et al., 1999) also observed the higher energy output-input ratio in pulse involving rice-based cropping pattern. Potato involving cropping pattern showed lower output-input energy compared to wheat and lentil involving pattern although the total yield of potato involving pattern was very high. It was due to maximum energy input required for potato crops. However, capsularis jute containing pattern always incurred higher output-input ratio than that of olitorius jute.

Table III. Energy output and output-input ratio of different cropping patterns (mean data of 3 years)

\begin{tabular}{l|c|c|c|c|c}
\hline Cropping pattern & $\begin{array}{c}\text { Energy input } \\
\text { (MJ ha }^{-1} \text { ) }\end{array}$ & \multicolumn{2}{|c|}{$\begin{array}{c}\text { Energy output } \\
\left(\mathrm{MJ} \mathrm{ha}^{-1}\right)\end{array}$} & $\begin{array}{c}\text { Total energy } \\
\text { output } \\
\text { (MJ ha }\end{array}$ & $\begin{array}{c}\text { Output- } \\
\text { Input } \\
\text { ratio }\end{array}$ \\
\cline { 3 - 4 } 1. Jute (cap.)-T. aman rice-Wheat & 31950 & 145282 & 258569 & 403851 & 12.6 \\
2. Jute (oli.)-T. aman rice-Wheat & 34932 & 144589 & 256743 & 401332 & 11.5 \\
3. Jute (cap.)-T. aman rice-Potato & 39856 & 176881 & 197068 & 373949 & 9.4 \\
4. Jute (oli.)-T. aman rice-Potato & 42928 & 177979 & 188750 & 366729 & 8.5 \\
5. Jute (cap.)-T. aman rice-Lentil & 24484 & 130848 & 211134 & 341982 & 14.0 \\
6. Jute (oli.)-T. aman rice-Lentil & 27556 & 125938 & 207478 & 333416 & 12.1 \\
7. Jute (cap.)-T. aman rice-Fallow & 19947 & 109426 & 179480 & 288906 & 14.5 \\
8. Jute (oli.)-T. aman rice-Fallow & 23028 & 109632 & 175635 & 285267 & 12.4 \\
9. Jute (cap.)-Fallow-Wheat & 21844 & 88180 & 173638 & 361818 & 12.0 \\
10. Jute (oli.)-Fallow-Wheat & 24905 & 84108 & 165398 & 249506 & 10.0 \\
\hline
\end{tabular}




\section{References}

Baishaya, A. and Sharma, G.L. (1990) Energy budgeting of rice-wheat cropping system. Indian J. Agron. 35(1\&2) : 167-177.

Bohra, C.P. and Maheshwari, R.C. (1983) Effect of energy inputs on productivity in various States of India during last two decades. Paper presented at the National Seminar on Contribution of Agricultural Machinery in Increasing Production and Productivity. Held at CIAE, Bhopal. Dec, 27, 1983-1984.

Eusuf, M.T.A. Bhuiyan, Hoque, M.S. and Khan, A. T. (1987). Heating values and proximate analysis of some traditional fuels of Bangladesh. Bangladesh J. Sci. Ind. Res. XXII (1-4) : 127-132.

Gautam, O.P. (1979) Keynote address presented at the XI Annual Workshop of All India coordinated Agronomic Research Projects. Jawharlal Neheru Krishi Vyswa. Vidyalaya, Jabbalpur, India.

Gurusawmy, T., Murthy, G.R.K. Desai, S.R. Mathew, M. and Veeranagoud, M. (1992) Energy use pattern for dryland crops in Mansalapur village__ A case study. Indian J. Agril. Engineer. 2(3) : 164-170.

Hasan, N. and Ahmad. K. (1990) Nutritional consideration of oil seeds and pulses in Bangladesh. Bangladesh J. Nutr. 4(1) : 7177.
Islam, AKM. Rahman, S.M.A. Sarker, R.I. Ahiduzzaman, M. and Baqui, M.A. (2001) Energy audit for rice production under power tiller and bullock farming system in Bangladesh. Online J. Biol. Sci. 1(9) : 873-876.

Khan, A.H. Akanda, R.U. and Magor, N.P. (1987) Major Agro-ecolgical Environments in Bangladesh. Presented at Regional Mutilocation Testing Review Meetings, November 1987, Bangladesh Rice Res. Inst., Joydebput, Gazipur.

Kiamco and McMennany, J. (1979) Reflection of the energy requirement of small rice farmers. AMA. 10 : 11-16.

Mittal, J.P. and Dhawan, K.C. (1988) Research Manual on Energy Requirement in Agricultural Sector, Coll. Agric. Engg., Punjab Agric. Univ., Ludhiana, India.

Parihar, S.S., Pandey, D. Shukla, R.K. Verma, V.K. Chaure, N.K. Choudhary, K.K. and Pandya, K.S. (1999) Energetics, yield water and economics of rice-based cropping system. Indian J. Agron. 44(2) : 205-209.

Sarker, R.I. (2000) Energy use pattern in small farm systems of Bangladesh. J. Agric. \& Mech., 4 : 29-44.

Received : November 19, 2006;

Accepted : May 6, 2007 